\title{
REPRESENTASI IDEOLOGI DALAM STRUKTUR WACANA KATA HARI INI
}

\author{
Mohamad Zubad Nurul Yaqin
}

\author{
zubadnurul@ymail.com \\ Fakultas Humaniora \\ Universitas Islam Negeri Maulana Malik Ibrahim Malang
}

\begin{abstract}
Abstrak: Penelitian ini bertujuan memerikan representasi ideologi dalam struktur wacana Kata Hari Ini (KHI). Pembahasan difokus-kan pada representasi ideologi dalam struktur mikro, struktur super, dan struktur makro. Data utama berupa praktik kebahasaan yang merepresentasikan ideologi di dalam struktur wacana KHI. Sumber data berupa transkripsi (teks) wacana KHI. Data dalam penelitian kualitatif dengan ancangan analisis wacana kritis ini dikumpulkan dengan teknik dokumentasi dan dianalisis dengan mengikuti model analisis wacana kritis perspektif van Dijk. Hasil menunjukkan bah-wa wacana $K H I$ memiliki keunikan tersendiri terutama dalam hal strukturnya. Temuan struktur mikro: kata, kalimat, dan gaya bahasa tertentu digunakan oleh penyampai wacana untuk menyampaikan pesan-pesan ideologisnya. Temuan struktur super: wacana KHI ter-diri dari tiga bagian (awal, tengah, dan akhir). Bagian awal, dimulai dengan pernyataan-pernyataan sederhana (umumnya berupa ideide konseptual suatu objek). Bagian tengah, berisi klaim pembenar. Bagian akhir, berisi pernyataan-pernyataan simpulan. Setiap bagian tersebut memuat jenis-jenis dan polapola ideologi tertentu. Temu-an struktur makro: tema wacana $\mathrm{KHI}$ merepresentasikan ideologi sebagai sistem keyakinan dan sebagai sistem tindakan. Intinya, as-pek kebahasaan dan nonkebahasaan digunakan penyampai wacana sebagai strategi penyampaian pesan agar pesannya dapat diterima, dibenarkan, dipercaya, dan akhirnya diharapkan dapat mengubah sikap dan keyakinan publik.
\end{abstract}

Keywords: representasi, ideologi, struktur wacana

\section{PENDAHULUAN}

Acara Kata Hari Ini (KHI) merupakan sebuah bentuk wacana yang disiar-kan melalui media radio. Acara ini merupakan salah satu program dari Yayasan Komunikasi Bersama (YKB). Fokusnya mengarah pada upaya memberitakan Injil dengan cara damai menggunakan berbagai metode yang dapat dirasakan sebagai berkah bagi masyarakat.

Visi YKB adalah berupaya meningkatkan martabat hidup (mencerdaskan bangsa) dengan berlandaskan pola hidup dan etika Kristiani. Misi YKB adalah menyampaikan Injil melalui program-program rohani yang berlandaskan etika Kristiani, mengadakan kursus-kursus dan seminar-seminar pelayanan Kristiani, mengadakan berbagai kegiatan yang dapat meningkatkan kerja sama antargereja, menjalin kemitraan dengan gereja-gereja atau lembaga-lembaga Kristen lainnya, membuka peluang bagi umat Kristiani untuk mengekspresikan imannya melalui YKB, serta mengadakan usaha-usaha lain yang tidak bertentangan dengan hukum dan tidak menyimpang dari visi YKB melalui media massa (cetak dan elektronik).

Sehubungan dengan visi dan misi YKB tersebut, perlu disadari bahwa Indonesia merupakan negara dengan kondisi masyarakat yang majemuk (diantara-nya dalam memeluk agama dan aliran kepercayaan). Kemajemukan tersebut sah secara hukum dan tidak dapat diganggu gugat oleh siapapun. Berdasarkan fakta tersebut, tidak berlebihan apabila acara KHI perlu dikritisi lebih lanjut, sebab di-sinyalir 'ada 
sesuatu di balik sesuatu' atau 'bertendensi ideologis tertentu'.

Ideologi dalam acara $\mathrm{KHI}$ disampaikan dengan menggunakan bahasa ter-tentu dan dengan strategi penyampaian tertentu pula (secara tidak terang-terangan atau disamarkan). Akibatnya, masyarakat Indonesia (sebagai sasaran/objek) tidak menyadari bahwa secara tidak langsung telah didominasi, telah diatur, dan telah dikontrol oleh pihak-pihak penghasil wacana $K H I$. Atau, acara $K H I$ pada dasarnya merupakan sebuah bentuk praktik sosial yang sengaja diciptakan oleh pihak YKB untuk tujuan-tujuan atau tendensi ideologis tertentu. Jadi, bahasa yang digunakan tidak hanya sebagai 'alat' menjelaskan berbagai kenyataan sosial tapi juga diguna-kan sebagai 'produksi makna' sesuai dengan tujuan dan kepentingan pihakpihak YKB. Pemakaian bahasa yang demikian menurut Berger dan Luckman (1976) merupakan mekanisme utama dalam proses konstruksi sosial, merupakan alat un-tuk berkonsolidasi dan mengontrol konsep.

Dalam tinjauan wacana kritis, wacana KHI dapat dikaji dari berbagai as-pek, baik aspek kebahasaan maupun non kebahasaan. "Apa makna setiap aspek kebahasaan yang digunakan dalam wacana KHI?", "Mengapa aspek kebahasaan tersebut digunakan?", "Bagaimana strategi penyampaiannya?", dan berbagai per-tanyaan lain dapat diajukan untuk menggali berbagai fenomena dalam wacana tersebut sehingga maksud sesungguhnya (tendensi ideologis) dapat terungkap.

Berdasarkan ilustrasi di atas, tampak jelas bahwa wacana KHI memiliki 'kekuatan' tertentu yang tidak alami dan tidak objektif (hubungan yang sengaja diciptakan, hubungan sosial yang dikonstruksikan dari realitas intersubjektif). Fenomena penggunaan bahasa yang demikian oleh Berger dan Luckman (1976), disebut sebagai "relationships in the area of power and control (as well as other areas of social and ideological structure" (Lihat Titcher, 2000; dalam Ibrahim, 2009, h. 36-39). Dengan demikian, peristiwa komunikasi dalam acara KHI merupa-kan fenomena yang layak dikaji (dikritisi) lebih lanjut karena tidak hanya sekadar berhubungan dengan aspek kebahasaan, tetapi ada hal penting lainnya yang ber-sifat non kebahasaan (bertendensi ideologis tertentu).
Acara KHI disusun dengan memperhatikan aspek kebahasaan dan aspek nonkebahasaan. Oleh karena itu, acara KHI bukan hanya dipandang sebagai teks, tetapi dipandang sebagai wacana karena disusun dengan memperhatikan aspek kohesi, koherensi, intensionalitas, akseptabilitas, informativitas, situasionalitas, dan aspek intertekstualitas. Peristiwa komunikasi dikategorikan sebagai 'wacana' apabila memenuhi kriteria-kriteria tersebut (Lihat De Beaugrande \& Dressler, 1981, h.1). Atau, KHI dikategorikan sebagai wacana karena merupakan peristiwa komunikasi yang mencakup tiga dimensi, yakni: teks (tuturan, ciri-ciri linguistik teks), praktik kewacanaan (proses yang berhubungan dengan produksi dan kon-sumsi teks), dan praktik sosial (praktik yang lebih luas yang mencakup peristiwa komunikasi) (Jorgensen \& Phillips; dalam Ibrahim, 2010, h. 126-128). Akibatnya, wacana $K H I$ juga memberikan konstribusi pada pengonstruksian identitas sosial (fungsi identitas), hubungan sosial (fungsi relasional), dan sistem pengetahuan dan makna (fungsi ideasional) (lihat Fairclough, 1998).

Wacana merupakan teks dalam konteks dan sebagai bukti yang harus diuraikan secara empiris. Oleh karena itu, wacana hendaknya dipahami sebagai tindakan (van Dijk, 1977). Dalam konteks Critical Discourse Analysis, pendapat tersebut sejalan dengan Fairclough \& Wodak (1997), bahwa Critical Discourse Analysis (CDA) memandang wacana - bahasa yang digunakan dalam tuturan dan tulisan sebagai bentuk praktik sosial, yakni menyiratkan adanya hubungan dialektik antara sebuah peristiwa diskursif tertentu dengan situasi, institusi, dan struktur sosial yang mewadahinya (peristiwa diskursif dibentuk oleh maupun juga membentuk situasi, institusi, dan struktur sosial tersebut) (lihat Ibrahim, 2009, h.44). Oleh karena itu, wacana merupakan bagian penting dari realita serta permasalahan kekuasaan dan ideologi sangat erat kaitannya dengan wacana. Atau, wacana me-miliki peran fundamental dalam siklus reproduksi kekuatan sosial (lihat van Dijk, 2004, h.21). Berdasarkan konsep tersebut, acara KHI hendaknya tidak hanya dipan-dang sebagai 'teks', tetapi juga sebagai 'wacana'. Jadi, struktur teks dan makna dalam acara $K H I$ merupakan kajian penting dan tidak bisa dipisahkan. 
Secara lebih spesifik, van Dijk (1983) menyatakan bahwa strukur wacana erat kaitannya dengan 'teks, konteks, pengetahuan, dan ideologi'. Teks dan penge-tahuan tidak mungkin tanpa adanya kontrol konteks, dan wacana yang relevan se-cara sosial lebih banyak adalah ideologi. Oleh karena itu, kajian wacana tidaklah cukup jika hanya difokuskan pada analisis teksnya semata. Sebab, wacana tercipta karena adanya teks, konteks, pengetahuan, dan ideologi. Unsur-unsur tersebut merupakan hal penting dalam mendefinisikan relasi koherensi antar kalimat untuk membangun struktur global makna (struktur makro/tema) dan struktur global ben-tuk (struktur super/skema). Struktur wacana menunjukkan sejumlah gagasan dan ideologi tertentu, atau wacana merupakan suatu tata aturan umum (macrorule). Jadi, wacana tidak hanya mencerminkan pandangan tertentu, tetapi juga mencerminkan suatu pandangan yang koheren, yakni diarahkan pada bagian-bagian wa-cana yang saling mendukung satu sama lain untuk menggambarkan tema umum dengan tujuan tertentu. Atas berbagai pandangan itulah van Dijk membagi struk-tur wacana menjadi tiga jenis, yakni: struktur mikro, struktur super, dan struktur makro. Ketiga-tiganya merupakan satu kesatuan yang saling mendukung untuk mencapai tujuan tertentu.

Struktur mikro merupakan makna lokal suatu teks yang bersifat konkret yang dapat diamati dari segi pilihan kata, kalimat, dan gaya bahasa yang dipakai dalam suatu teks (van Dijk \& Kintsch, 1983, h.272). Struktur mikro terbagi empat sisi, yakni: semantik, sintaksis, stilistik, dan retoris (lihat Erianto, 2001). Dalam telaah kritis, struktur mikro dipandang sebagai makna wacana yang dapat diamati dengan menganalisis kata dan proposisi yang ditampilkan (struktur kalimat atau bagaimana pendapat disampaikan). Analisis deskripsi mencakup tiga aspek, yakni: kosakata, gramatika, dan struktur teks (Fairclough, 1995).

Struktur super berhubungan dengan kerangka teks, bagaimana bagian-bagian teks tersusun ke dalam berita/cerita yang utuh. Struktur super merupakan pengetahuan yang berhubungan dengan area isi. Unsur-unsurnya meliputi skema-tik, aktor, strategi, dan latar. Pengetahuan mengenai unsur-unsur tersebut dapat membantu melahirkan, mengingat, dan mereproduksi struktur makro (van Dijk, 1983, h.54).

Struktur makro merupakan makna global (tema/ inti sari) wacana (van Dijk \& Kintsch, 1983, h.52). Makna tersebut dapat dilihat dari segi struktur makro semantik, tingkat kognitif, grammar-semiotik, makna semantik, aksi makro, dan struktur makropragmatik (van Dijk, 1977, h.2-5). Tema (makna global/ top level) tersebut didukung oleh sub-subtema (sub-subtopik/lowes level). Dan sub-subtema tersebut didukung oleh serangkaian fakta yang menunjuk dan menggambarkan tema (van Dijk, 1986, h.136). Subbagian yang saling mendukung tersebut mengha-silkan teks yang koheren dan utuh. Hal ini dapat dikaji misalnya dari segi judul, rangkuman, kesimpulan, pernyataan, dsb., yang masing-masing tidak lepas dari unsurunsur pembentuknya, yakni: kata, larik, dan bait, atau kata, klausa, dan ka-limat (van Dijk, 1985; Bown \& Yule, 1996; Haliday-Hasan, 1992; Dodjosuroto, 2006, h. 25).

Mengacu pada pembagian struktur wacana di atas, teks, kognisi sosial, dan konteks sosial merupakan bagian integral dalam kerangka van Dijk. Dalam hal ini, van Dijk bermaksud menghubungkan antara struktur yang sangat mikro (wacana) dengan struktur yang sangat makro (masyarakat). Argumennya: (1) Model kognisi sosial (representasi susunan masyarakat yang dipaparkan secara sosial, seperti: tindakan, interpretasi, dan interaksi yang menekankan pada organisasi sosial dan kultural masyarakat secara keseluruhan); (2) Konteks sosial (situasi apa dan bagai-mana pengetahuan dan pendapat seseorang disampaikan); serta (3) Struktur wa-cana, aspek kebahasaan yang digunakan sebagai 'alat' mempengaruhi pendapat umum, mempertahankan legitimasi, menciptakan dukungan, dan memarjinalkan komunitas yang lain. Tiga hal inilah yang dimaksudkan sebagai struktur wacana yang dipakai secara efektif untuk menyampaikan pesan tertentu yang bersifat ideologis. Singkatnya, di balik ketiga struktur wacana tersebut terdapat informasi (pengetahuan dan keyakinan) yang bersifat ideologis (lihat Resnick dalam van Dijk, tt,c, h.14).

Sehubungan dengan wacana KHI, keberadaan struktur tersebut merupakan kajian penting karena ketiga-tiganya 
merupakan satu kesatuan yang saling mendukung untuk mencapai tujuan tertentu (tendensi ideologis) yang diharapkan pihakpihak penghasil wacana KHI. Kajian terhadap struktur tersebut dapat membantu peneliti dalam menjawab fokus penelitian sehingga dapat diperoleh gambaran dan penjelasan secara menyeluruh mengenai wacana $\mathrm{KHI}$ (aspek kebahasaan maupun non kebahasaan).

Karakteristik utama wacana $\mathrm{KHI}$ adalah (1) Merefleksikan sebuah kata yang dibahas secara ilmiah, singkat, dan menarik didengar; (2) Isi bersifat sangat umum namun selalu terarah pada pola kehidupan yang dilandasi etika Kristiani sehingga mampu menginspirasi untuk mengubah perilaku para penggemarnya; (3) Memiliki struktur wacana yang unik; (4) Menggunakan strategi penyampaian pe-san tertentu; serta (5) Disusun dengan memperhatikan aspek kekohesian, kekohe-rensian, kekhasan diksi, kekhasan kalimat, dan kekhasan gaya bahasa. Berbagai fenomena tersebut menarik untuk dikaji lebih jauh, khususnya yang berhubungan dengan tendensi ideologi di dalamnya. Penelitian ini juga dilakukan atas berbagai pertimbangan tersebut.

Berdasarkan latar belakang di atas, pembahasan penelitian difokuskan pa-da representasi ideologi dalam struktur wacana KHI. Tujuan umum, mendapatkan deskripsi, interpretasi, klarifikasi, dan eksplanasi tentang representasi ideologi dalam struktur wacana KHI. Tujuan khusus, mendapatkan deskripsi, interpretasi, klarifikasi, dan eksplanasi tentang representasi ideologi dalam struktur mikro (pilihan kata, pilihan kalimat, dan pilihan gaya bahasa), struktur super (skema), dan struktur makro (tema).

\section{METODE PENELITIAN}

Penelitian ini menggunakan pendekatan kualitatif karena mengkaji peris-tiwa komunikasi yang mencakup aspek kebahasaan dan aspek non kebahasaan (ideologi). Analisisnya memanfaatkan ancangan analisis wacana kritis perspektif van Dijk yang difokuskan pada keberadaan ideologi dalam struktur wacana (struk-tur makro, struktur super, dan struktur mikro). Untuk menajamkan analisis, juga dimanfaatkan teori AWK Faucoult, Fairclough, dan Wodak. Pendekatan kualitatif jenis analisis wacana kritis ini digunakan untuk mendeskripsikan, menginterpretasikan, dan mengeksplanasikan representasi ideologi dalam struktur wacana KHI.

Data utama berupa praktik kebahasaan (pilihan kata, pilihan kalimat, pilih-an gaya bahasa, skema, dan tema) yang merepresentasikan ideologi dalam struktur wacana KHI. Acara KHI disiarkan melalui media radio yang direkam dan ditrans-krip oleh peneliti. Jadi, sumber data berupa transkripsi (dokumen/teks) wacana KHI yang merepresentasikan ideologi.

Sebagai upaya untuk memudahkan pengumpulan data, peneliti (instrumen utama) melengkapi diri dengan instrumen pendukung berupa tape record dan pan-duan pengumpulan data. Untuk mendukung kecermatan dalam analisis dan penaf-siran data, peneliti melengkapi diri dengan carta analisis.

Data dikumpulkan dengan teknik
dokumentasi dengan memanfaatkan instrumen-instrumen yang ada. Dokumen yang dimaksud berupa barang tertulis (teks $K H I$ ) yang tidak dipersiapkan secara khusus atas permintaan peneliti. Tahap-an pengumpulan data adalah mendengarkan dan merekam secara rutin siaran $K H I$, mendengarkan dan mentranskrip rekaman acara KHI, serta mengumpulkan berba-gai informasi yang berhubungan dengan data penelitian. Selain itu, peneliti juga melakukan komunikasi dengan pihak YKB untuk mendulang informasi sebanyak-banyaknya guna keperluan penelitian.

Prinsipnya, setiap data dikumpulkan, diklasifikasikan, dan dianalisis sesuai dengan fokus penelitian. Tekniknya adalah mengumpulkan, mengklasifikasikan, dan selanjutnya menganalisis data dari segi representasi ideologi dalam struktur wacana $K H I$, dan selanjutnya akan tampak pola representasi ideologi pada setiap struktur wacananya. Verifikasi data dilakukan dengan memanfaatkan teknik tri-angulasi dengan pakar bahasa dan orang-orang yang kompeten dengan program YKB.

\section{HASIL DAN PEMBAHASAN}

Hasil penelitian menunjukkan bahwa struktur wacana $K H I$ (struktur mikro, struktur super, dan struktur makro) merepresentasikan ideologi tertentu. 


\section{Representasi Ideologi dalam Struktur Mikro Wacana KHI}

Representasi ideologi dalam struktur mikro wacana KHI meliputi pilihan kata, pilihan kalimat, dan representasi idelogi dalam gaya bahasa.

Representasi Ideologi dalam Pilihan Kata

Dalam tataran pemakaian kata, unsur yang menampak (paling dominan) adalah pemakaian kata persona (terdapat pada hampir semua bagian wacana), yak-ni kata saudara, kita, ia, anda, dan mereka. Juga digunakan kata manusia, Indone-sia, warga negara, dan masyarakat (variasi dari kata kita) serta kata negara, pe-merintah, dan penyelenggara (variasi kata mereka). Katakata tersebut memang sengaja dipilih (digunakan) sebagai strategi komunikasi, yakni sebagai alat untuk menunjukkan posisi penyampai wacana di mata publik.

Kata saudara dan anda, umumnya digunakan untuk mengawali komuni-kasi, menyampaikan informasi berupa ide-ide konseptual, menyampaikan infor-masi sekaligus klarifikasi mengenai suatu hal, dan digunakan penyampai wacana ketika ingin menasihati dan sekaligus mempersuasi publik (berhubungan dengan sikap dan keyakinan). Secara khusus, kata saudara sengaja digunakan untuk men-jalin keakraban dengan publik agar tercipta kesejajaran posisi (tidak adanya jarak atau perbedaan tingkat sosial). Penyampai wacana umumnya menggunakan kata saudara ketika ingin menyampaikan gagasan yang tidak kontroversial (gagasan sudah dimaklumi oleh publik) dan ketika ingin menyajikan tema (topik) yang me-merlukan pemecahan.

Kata kita, digunakan penyampai wacana dalam konteks ingin menyampai-kan sesuatu yang berhubungan dengan kepercayaan, rencana, suasana hati, sikap, harapan, ajakan, dan seruan. Selain itu, digunakan dalam konteks ingin memberi-kan informasi mengenai sesuatu yang sudah umum dan yang tidak diragukan lagi kebenarannya, memberi informasi sekaligus klarifikasi mengenai sesuatu, serta ketika ingin menasihati sekaligus ingin mempersuasi publik mengenai sesuatu yang berhubungan dengan sikap atau keyakinan. Penggunaan kata kita berakibat pada tidak tampaknya dikotomis antara dirinya dengan publik (jadi bermaksud menciptakan komunitas antara dirinya dengan publik) agar sesuatu yang menjadi gagasan penyampai wacana juga diharapkan menjadi gagasan publik. Setidaknya, publik dilibatkan dalam proses berpikir sehingga mau menerima atau menolak in-formasi yang disampaikan. Kata manusia, masyarakat, warga negara, Indonesia, dan kata negara Indonesia juga digunakan untuk maksud yang sama dengan kata kita. Bedanya, kata-kata tersebut penggunaannya lebih fleksibel (berlaku untuk semua manusia di dunia ini).

Kata ia dan dia, utamanya digunakan pada pernyataan-pernyataan yang berisi contoh-contoh berbagai fenomena faktual yang berhubungan dengan topik yang sedang dibicarakan (sebagai klaim pembenar). Katakata yang terdapat pada hampir seluruh bagian wacana tersebut digunakan dengan tujuan agar tercipta jalinan komunikasi yang harmonis. Kata-kata tersebut umumnya digunakan untuk menyampaikan informasi, menasihati, dan mempersuasi publik yang dilakukan secara tidak langsung (melalui contoh-contoh mengenai baik-buruknya perilaku manusia dan dampaknya). Hal ini merupakan strategi penyampaian pesan, yakni agar tidak terkesan adanya dikotomis antara penyampai wacana dengan publik, agar posisi dirinya sebagai orang yang mendominasi komunikasi tetap dipandang baik oleh publik, dan agar ia lebih leluasa dalam menyampaikan pesan-pesan ideologisnya.

Kata mereka, digunakan penyampai wacana dalam konteks ingin membe-rikan informasi, menasihati, dan mempersuasi publik dengan cara tidak langsung (melalui teknik contoh-contoh atau teknik generalisasi) seperti halnya kata ia atau dia. Kata pemerintah dan penyelenggara negara juga digunakan untuk maksud yang sama dengan kata mereka. Bedanya, kata pemerintah dan penyelenggara negara lebih fleksibel, yakni dapat ditujukan (digunakan) untuk semua pemerin-tah yang ada di seluruh dunia. Penyampai wacana menggunakan kata pemerintah ketika mengungkapkan sikap, seruan, dan harapan sebagai upaya mempersuasi publik. Secara khusus, kata pemerintah digunakan oleh penyampai wacana ketika menyampaikan informasi yang berkaitan dengan hukum, ketatanegaraan, pelayan-an publik, dan perlindungannya. Dengan kata pemerintah atau kata 
penyelenggara negara), penyampai wacana seolah-olah ingin menempatkan dirinya sebagai pi-hak yang bertanggung jawab atas berlangsungnya pemerintahan (seolah-olah ia berposisi sebagai pemerintah).

Singkatnya, berbagai kata persona di atas merupakan strategi penyampaian pesan agar pesannya dapat diterima, dapat dipercaya, dapat dibenarkan, dan akhir-nya diharapkan publik mau mengubah sikap dan tindakan sesuai dengan harapan penyampai wacana. Dengan demikian, jelas bahwa pemilihan (penggunaan) kata-kata tersebut memang bertendensi ideologis. Hal ini menjadi bukti bahwa aspek kosa kata tidak semata persoalan teknis, tetapi sebagai praktik ideologi. Pilihan kata dalam suatu teks menandai secara sosial dan ideologis bidang pengalaman yang berbeda dari penulisnya (lihat Fairclough, 1995).

\section{Representasi Ideologi dalam Pilihan Kalimat}

Wacana KHI diekspresikan dalam bentuk rangkaian kalimat. Berdasarkan tujuan, kalimat yang diekspresikan berbentuk kalimat pernyataan (deklaratif), pertanyaan, ajakan, seruan, dan kalimat harapan. Berdasarkan struktur, berbentuk kalimat aktif dan kalimat pasif. Setiap jenis kalimat tersebut bertendensi ideologis.

Kalimat pernyataan (berita), adalah kalimat yang isinya memberitahukan sesuatu. Jenisnya berupa kalimat berita inversi, kalimat berita aktif, kalimat berita pasif, dsb. Dalam wacana $K H I$, berbagai jenis kalimat berita tersebut digunakan untuk tujuan tertentu (bertendensi ideologis), yakni mempersuasi publik untuk membentuk pola pikir, perilaku, dan keyakinan.

Kalimat tanya, adalah kalimat yang isinya menanyakan sesuatu, seseorang, keadaan, atau masalah. Kalimat tanya tersebut umumnya sudah disertai dengan jawaban. Hal ini merupakan strategi untuk menjaga posisi penyampai wacana $K H I$ sebagai orang yang mendominasi komunikasi dalam menyampaikan pesan-pesan ideologisnya. Dengan kalimat tanya, secara tidak langsung publik dikondisikan untuk selalu berperan aktif (selalu terlibat) dalam praktik komunikasi yang sedang berlangsung.

Kalimat ajakan, adalah kalimat yang isinya mengajak publik (tindakan, pi-kiran, maupun sikap). Nuansa yang menampak adalah "kebersamaan" (penyampai wacana ingin menghilangkan jarak dengan publik). Jadi, rumusan kalimat ajakan dalam wacana $K H I$ tidak terasa memaksakan kehendak (yang dituntut adalah ke-sadaran). Agar ajakannya dapat diterima, kalimat ini biasanya diawali atau diikuti dengan rasionalisasi yang disesuaikan dengan kondisi (pola pikir) publik.

Kalimat perintah, adalah kalimat yang berisi perintah untuk melakukan se-suatu (publik diharapkan melakukan seruan atau sesuatu yang diperintahkan, baik berupa tindakan maupun sikap). Jadi, di dalamnya terkesan ada jarak (perbedaan) antara penyampai wacana $K H I$ dengan publik (penyampai wacana secara tidak langsung menunjukkan posisi dirinya sebagai aktor yang mendominasi peristiwa komunikasi.

Kalimat harapan, adalah kalimat yang isinya mengharapkan publik agar bisa melakukan tindakan atau sikap sesuai dengan keinginan penyampai wacana. Apabila kalimat seruan bernuansa 'atas-bawah', maka kalimat harapan bernuansa 'kesetaraan'. Kalimat ini digunakan ketika penyampai wacana $\mathrm{KHI}$ merasa tidak memiliki otoritas memaksakan kehendak (apa yang diinginkannya). Sebaliknya, menerima ataukah menolak menjadi otoritas publik.

Kalimat pasif, adalah kalimat yang memiliki subjek (S) predikat (P), dan objek (0). Jika subjek dalam kalimat aktif dijadikan objek, maka akan menjadi kalimat pasif. Dalam perspektif wacana kritis, aktif-pasifnya kalimat tidak hanya dikaji berdasarkan tatabahasanya, melainkan dipandang ada 'sesuatu' (pajanan ideologi) yang ingin ditunjukkan pada publik, terutama ideologi kekuasaan (ada yang memerintah dan ada yang diperintah, ada yang menasihati dan ada yang di-nasihati, dsb.). Strateginya, dengan cara menghilangan (melesapkan) pelaku atau subjek pada kalimat pasif tersebut (hal ini merupakan strategi pemarjinalan suatu komunitas, sehingga citra pelaku tetap baik di mata publik). Pelaku sebagai orang yang mengatur, mendominasi, mendikte, dsb. tidak dimunculkan oleh penyampai wacana. Jelas bahwa kalimat aktif diubah menjadi kalimat pasif bukan hanya ber-kaitan dengan masalah enak-tidaknya dibaca atau dipahami, akan tetapi secara tidak langsung ada pemanipulasian (lihat Fowler, 1996). 
Kalimat aktif, adalah kalimat yang memiliki subjek $(\mathrm{S})$, predikat $(\mathrm{P})$, dan objek (0). Umumnya, subjek dalam kalimat ini berperan aktif (melakukan sesuatu perbuatan). Artinya, pelaku tampak mendominasi (sebagai subjek yang mampu mendefinisikan suatu peristiwa atau kelompok tertentu) dalam peristiwa komunikasi. van Dijk menyebutnya sebagai interaksi atas-bawah (top-down), yakni suatu interaksi yang dikonstruksi aktor (pelaku) untuk membangun citra dirinya sebagai pendominasi (pengatur, penasihat, dsb.) pada setiap peristiwa komunikasi. Dalam interaksi 'atas-bawah' tersebut tidak akan pernah ditemukan bahwa aktor (pelaku) berada pada posisi sebagai orang yang didominasi. Ini sejalan dengan Fairclough (1998), yang memusatkan perhatian pada tipe tatabahasa yang dipilih dan pelaku yang mendominasi suatu peristiwa. Pengungkapan suatu realitas sosial, biasanya menjadi pilihan yang berbeda dalam proses gramatika dan bentuk partisipan yang telah dikonstruksi secara ideologis yang signifikan. Karena bersifat satu arah (top-down), di dalamnya sudah pasti terjadi suatu kegiatan konstruksi terhadap sesuatu, yakni 'sesuatu' dikonstruksi aktor (S) untuk membangun citra dirinya sebagai 'orang yang mendominasi'.

Berdasarkan uraian di atas, dapat ditegaskan bahwa berbagai jenis kalimat dalam wacana $K H I$ digunakan karena tujuan (tendensi ideologis) tertentu. Kalimat merupakan bagian terkecil wacana yang diciptakan individu (komunitas tertentu) dan dengan tujuan tertentu pula. Ide dan pandangan hidup dikonstrusi dalam kon-disi tertentu sehingga mempersuasi publik untuk membentuk pola pikir, perilaku, dan keyakinan seseorang/suatu komunitas (lihat Foucoult, 1997). Jadi, kalimat dalam wacana KHI tidak hanya dilihat segi kepraktisannya, akan tetapi terdapat informasi yang bermuatan ideologis tertentu yang berkaitan dengan kekuasaan. Tentunya, ini merupakan upaya sadar, terencana, dan secara sengaja dilakukan oleh penyampai wacana untuk mempertahankan posisi dirinya, agar citranya tetap baik di mata publik.

\section{Representasi Ideologi dalam Gaya Bahasa}

Gaya bahasa tertentu digunakan penyampai wacana ketika ingin memberi-kan penekanan tertentu agar publik dapat memahami pesan dengan efektif. Gaya bahasa dalam wacana $K H I$ berupa gaya bahasa eufimisme, pleonasme, simile, paradoks, hiperbola, paralelisme, dan repetisi.

Gaya bahasa eufimisme, adalah penyampaian gagasan yang dilakukan dengan cara memilih kata (istilah) berkonotasi sopan (menyenangkan dan tidak menyinggung perasaan), sebagai strategi mempertahankan posisi penyampai wa-cana sebagai pengendali komunikasi (strategi tersebut segaja disamarkan). Akibat-nya, publik tidak menyadarinya dan tidak berpikiran negatif (misalnya merasa di-gurui, merasa dianggap sebagai orang yang kurang berpengetahuan, dsb.).

Gaya bahasa pleonasme, adalah penyampaian gagasan yang dilakukan dengan cara memilih kata (istilah) berkonotasi sopan (menyenangkan dan tidak menyinggung perasaan) dengan maksud menonjolkan bagian tertentu yang diang-gap penting agar publik menaruh perhatian khusus terhadap sesuatu yang diang-gap penting tersebut. Praktiknya, dengan memberikan pengulangan arti yang sama (hampir sama) dengan katakataberbeda dengan tujuan agar di dalam diri publik timbul perasaan 'tidak ada jarak' (tidak dianggap sebagai orang lain) dan 'muncul pikiran positif' (misalnya, publik akan menilai penyampai wacana sebagai orang yang pandai dalam memilih kata-kata, sopan, dan piawai dalam berbahasa).

Gaya bahasa simile, adalah penyampaian pesan yang dilakukan dengan cara memilih kata atau istilah dengan maksud membandingkan 'sesuatu' dengan 'sesuatu yang lain' yang dianggap memiliki persamaan agar publik dapat mema-hami dan sekaligus mau memperhatikan pesan yang disampaikan. Cara ini terasa mudah dipahami dan menarik perhatian ketika sesuatu yang dipakai perbandingan telah menjadi isu atau opini masyarakat.

Gaya bahasa paradoks, adalah penyampaian pesan yang dilakukan dengan cara memilih kata/istilah tertentu dengan maksud mempertentangkan dua hal yang dianggap memiliki perbedaan agar publik selalu terlibat dalam penalaran yang dipolakan penyampai wacana, sehingga pesan yang diungkapkan memperoleh pem-benaran publik. Publik diberi kebebasan untuk 
berpikir (menerima atau menolak) pesan tersebut.

Gaya bahasa hiperbola, adalah penyampaian pesan yang dilakukan dengan cara memilih kata-kata tertentu yang dianggap memiliki 'nuansa lebih' daripada kenyataan yang ada agar publik dapat memahami dan sekaligus mau memperhatikan secara lebih serius pesan tersebut. Intinya, penyampai wacana $K H I$ ingin memunculkan efek tertentu, diantaranya meningkatkan motivasi pada diri publik agar selalu terlibat dalam peristiwa komunikasi.

Gaya bahasa paralelisme, adalah penyampaian gagasan yang dilakukan dengan cara memilih kata-kata yang memiliki kesejajaran bentuk (kata, kelompok kata, atau klausa) untuk memberikan penekanan terhadap pesan dalam wacana KHI. 'Penekanan' tersebut dapat menimbulkan efek tertentu terhadap peristiwa komunikasi. Setidaknya, publik diharapkan lebih termotivasi, lebih tertarik, lebih serius, dan lebih mudah memahami pesan-pesan yang disampaikan.

Gaya bahasa repetisi, adalah penyampaian pesan yang dilakukan dengan cara mengulang unsur-unsur kebahasaan tertentu (kata, kelompok kata, klausa) karena dirasa perlu mendapatkan penekanan. Penggunaannya paling dominan dalam wacana KHI (kata kita, saudara, ia, manusia, orang dan kata-kata yang dijadikan sebagai judul wacana). 'Penekanan' tersebut mengindikasikan bahwa penyampai wacana sangat serius dalam menyampaikan pesan ideologisnya. Atau, 'pesan' yang disampaikan dipandang sebagai hal penting yang harus diketahui, harus diterima, harus dipercaya, dan harus dibenarkan publik.

Berdasarkan uraian di atas, dapat ditegaskan bahwa KHI merupakan wa-cana yang disusun dengan perencanaan sungguhsungguh (tidak asal-asalan), ter-utama aspek kebahasaannya (kosa kata, kalimat, dan gaya bahasa). Aspek kebaha-saan tersebut sengaja digunakan sebagai strategi penyampaian pesan agar pesan-nya dapat diterima, dapat dipercaya, dapat dibenarkan, dan akhirnya diharapkan dapat mengubah sikap dan keyakinan publik. Penggunaan aspek kebahasaan ter-sebut merupakan upaya sadar penyampai wacana untuk menciptakan kerjasama yang baik dalam peristiwa komunikasi (sebagai strategi mempertahankan posisi atau citra dirinya di mata publik). Jadi, aspek kebahasaan tersebut bertendensi ideologis tertentu, sebagai upaya melestarikan kekuasaan dan ideologinya. Hal ini menjadi bukti bahwa bahasa memang memiliki kekuatan (lihat Fairclough, 1989). Pilihan kata merupakan instrumen penting bagi media massa dalam menyampai-kan informasi kepada masyarakat (lihat Fairclough, 1995).

\section{Representasi Ideologi dalam Struktur Super Wacana $\mathrm{KHI}$}

Struktur super berhubungan dengan kerangka teks (merupakan pengetahu-an dengan area isi), yakni bagaimana bagianbagian tersebut tersusun ke dalam berita atau cerita yang utuh. Unsur-unsurnya meliputi skematik, aktor, strategi, dan latar.

Hasil analisis menunjukkan bahwa skema wacana $K H I$ terdiri dari tiga ba-gian, yakni: awal, tengah, dan bagian akhir. Pada bagian awal, dimulai dengan pernyataanpernyataan sederhana (eksplanasi/penerapan/ legalisasi ide) yang umumnya berupa ide-ide konseptual tentang suatu objek. Bagian tengah, berisi penjabaran lebih rinci (umumnya dengan menyajikan data-data faktual) sebagai klaim pembenar terhadap ide-ide yang disajikan pada bagian awal. Klaim pembe-nar dilakukan dengan cara penyampaian rasionalisasi, pembuktian efek dan dam-pak, dan atau piranti pembenar lain. Bagian akhir, berisi peryataan-pernyataan sebagai simpulan. Selain itu, dalam setiap bagian wacana $\mathrm{KHI}$ memuat pajanan ideologiidelogi tertentu dan dengan pola pajanan ideologi yang tertentu pula, yakni: ideologi sebagai sistem pemikiran (sP), ideologi sebagai sistem tindakan (sT), dan ideologi sebagai sistem keyakinan (sK). Pola pajanan ideologinya: pola satu, pada bagian awal dan tengah berisi pajanan ideologi sebagai sistem pemikir-an serta bagian akhir berisi pajanan ideologi sebagai sistem tindakan (sP-sP-sT); dan pola dua, pada bagian awal berisi pajanan ideologi sebagai sistem pemikiran, serta pada bagian tengah dan akhir berisi pajanan ideologi sebagai sistem tindakan (sP-sT-sT).

Dari temuan tersebut, dapat ditegaskan bahwa wacana $K H I$ disusun secara sungguhsungguh (direncanakan) dan bertendensi ideologi tertentu. Dikatakan demikian karena 
adanya keseragaman pola pajanan ideologi dalam setiap struktur supernya. Dengan tendensi-tendensi tersebut, secara tidak langsung mengindikasi-kan bahwa ada upayaupaya untuk mendominasi (memarginalkan, menguasai, dsb.) kelompok-kelompok tertentu (publik). Melalui akses yang dikuasainya (me-dia radio), penyampai wacana mampu dengan leluasa memperlihatkan, mendra-matisasikan, dan memopulerkan serangkaian fragmen sosial, kultural, dan apa saja yang dianggap dapat mendukung atau melestarikan ideologinya (lihat Williams, 1985, h.153). Ini menunjukkan bahwa wacana KHI merupakan bentuk 'pemahaman dan komitmen sosial', 'sebagai pemikiran dan cara pandang', sekaligus sebagai 'pemikiran dan tindakan'. Ideologi dalam wacana $\mathrm{KHI}$ melahirkan peta pemikiran individu atau kelompok (publik) bagaimana seharusnya mengondisikan dirinya dalam lingkungan sosial tertentu.. Dengan demikian, ideologi dalam wacana $\mathrm{KHI}$ menjadi formulasi panduan tingkah laku publik dan juga sekaligus menjadi patok-an publik dalam menilai tingkah laku tersebut (lihat Nurdyana, 2007, h.28).

Rangkaian gagasan ideologis pada setiap bagian wacana KHI tentunya bu-kan merupakan sebuah praktik ideologi yang kehadirannya secara tiba-tiba (tidak disengaja), akan tetapi memang disengaja. Dalam teori wacana kritis, fenomena tersebut menjadi bukti bahwa wacana KHI tidak pernah lepas dari berbagai kepen-tingan tertentu (penanaman ideologi-ideologi tertentu) dari pihak-pihak yang berkepentingan di dalamnya. Dengan pernyataan lain, dalam sebuah wacana pasti 'ada sesuatu di balik sesuatu'.

\section{Representasi Ideologi dalam Struktur Makro Wacana $\mathrm{KHI}$}

Tema merupakan gagasan pokok (pokok pikiran) wacana (Djojosuroto, 2006, h.24). Tema merupakan gagasan dasar dan tujuan utama penulisan sebuah teks (Prodotokusumo, 2005, h.37). Berbagai cara dapat dilakukan dalam perumusan dan pemaknaannya, dan perumusan serta pemaknaannya berbeda antara penganalisis satu dengan yang lainnya.

Pengetahuan tentang bentuk-bentuk struktur super dapat membantu mela-hirkan, mengingat, dan mereproduksi struktur makro (van Dijk, 1983, h.54). Struk-tur makro terdiri atas struktur global makna (tema/makro) dan struktur global ben-tuk (struktur super/skema). Jadi, struktur makro dapat diketahui setelah mengana-lisis struktur supernya (van Dijk, 2004, h.1).

Hasil menunjukkan bahwa pajanan ideologi dalam tema wacana $K H I$ beru-pa 'ideologi sebagai sistem keyakinan' dan 'ideologi sebagai sistem tindakan'. Dengan demikian, tendensi ideologis dalam tema wacana KHI adalah mengajak (sengaja dan direncanakan dengan sungguh-sungguh) individu atau masyarakat (publik) untuk berkeyakinan dan berperilaku seperti yang diharapkan penyampai wacana (pihak YKB). Selain itu, setiap paragraf pada semua wacana KHI masing-masing memiliki satu ide pokok (subtema) yang keberadaannya didukung oleh klaim pembenar sehingga menghasilkan teks yang koheren dan utuh. Serangkaian fakta tersebut tidak lepas dari berbagai unsur pembentuknya, yakni: kata-kata dan kalimatkalimat dalam wacana (lihat van Dijk, 1985; Haliday, 1992, Bown \& Yule 1996; Dojosuroto, 2006, h.25).

\section{KESIMPULAN}

Wacana KHI memiliki keunikan tersendiri terutama dalam hal strukturnya, yakni selalu bertendensi ideologis tertentu. Dalam struktur mikro, terdapat pilihan kata, pilihan kalimat, dan pilihan gaya bahasa tertentu yang digunakan sebagai strategi menyampaikan pesan-pesan ideologis. Dalam struktur super, wacana $K H I$ terdiri dari tiga bagian, yakni: bagian awal (dimulai dengan pernyataan-pernyata-an sederhana yang umumnya berupa ide-ide konseptual suatu objek), pada bagian tengah (berisi penjabaran lebih rinci sebagai klaim pembenar, umumnya dengan menyajikan data-data faktual tentang ide-ide yang ditampilkan pada bagian awal), serta bagian akhir (berisi peryataanpernyataan simpulan). Dalam struktur makro, tendensi ideologi dalam tema wacana $\mathrm{KHI}$ adalah berupa ideologi sebagai sistem keyakinan dan ideologi sebagai sistem tindakan. Atau, mengajak (sengaja dan direncanakan) individu atau masyarakat (publik) untuk berkeyakinan dan berperi-laku seperti yang diharapkan oleh penyampai wacana (pihak YKB). Keberadaan struktur 
wacana $K H I$ tersebut (dengan berbagai fenomena di dalamnya), sengaja dikemas sedemikian rupa agar pesan ideologis yang disampaikan dapat dibenar-kan, dipercaya, dapat diterima, dan akhirnya diharapkan dapat mengubah sikap dan keyakinan publik.

Sehubungan dengan hal tersebut, penelitian ini dapat dimanfaatkan, baik secara teoretis maupun praktis. Secara teoretis, dapat menjadi pengaya bagi teori kewacanaan yang telah ada, khususnya yang berhubungan dengan keberadaan ideologi dalam struktur wacana. Secara praktis, dapat digunakan untuk berbagai keperluan, yakni: dapat dijadikan sebagai masukan bagi dosen atau guru bahasa dalam interaksi pembelajaran wacana, bahan pertimbangan bagi penyusun buku kewacanaan yang bertendensi ideologis (pembelajaran wacana, pidato, khotbah, dsb.), serta dapat dijadikan bahan pertimbangan bagi penceramah (dai, pastur, khotib, dsb.) dalam merencanakan, menyusun, dan menyampaikan ideologi dalam ceramahnya.

\section{DAFTAR PUSTAKA}

Brown G, Yule G. (1983). Discourse Analysis. Diterjemahkan oleh Soetikno. 1996. Jakarta: Gramedia Pustaka Utama.

Djojosuroto, Kinayati. (2006). Pengajaran puisi: Analisis dan Pemahaman. Bandung: Nuansa

Djojosuroto, Kinayati. (2006). Analisis Teks Sastra dan Pengajarannya. Yogyakarta: Pustaka

Eriyanto. (2001). Analisis Wacana: Pengantar Analisis Teks Media. Yokyakarta: Yokyakarta LKIS.

Fairclough, Norman. (2005). Analysing Discourse, Textual Analysis for Social Research. London and New York: Routledge.

Fairclough, Norman dan Wodak, Ruth. (1997). "Critical Discourse Analysis" Dalam Teun A. Van Dijk (ed.). Discourse as Social Interaction: Discourse Studies A Multidiciplinary Introduction. Vol. 2. London: Sage Publication.

Fairclough, Norman. (1995). Critical Discourse Analysis: the Critical Study of Language. New York: Longman Publishing.

Fairclough, Norman. (1995). Media Discourse. London: Edward Arnold.

Fairclough, Norman. (Ed). (1992). Critical Languange Awareness. New York: Longman Publishing. Terjemahan oleh Hartono. (1995). Kesadaran Bahasa Kritis. Semarang: IKIP Semarang Press.

Fairclough, Norman. (1989). Language and Power. England: Longman Group UK. Alih Bahasa oleh Rohmani Indah. (2003). Relasi Bahasa, Kekuasaan dan Ideologi. Boyan Publishing. Malang.

Foucault, Michael. (2002). Power of Knowlwdge. Terjemahan oleh Udi santoso. Yogyakarta: Bentang.

Haliday, MAK. (1992). Language as Social Semiotic, The Social Interpretation of Language and Meaning. London: The Open University Set Book.

Jorgensen, Marianne W dan Louise J. Phillips. Analisis Wacana: Teori dan Metode. Terjemahan Imam Suyitno, dkk. (Editor: Abdul Syukur Ibrahim). (2010). Surabaya: Pustaka Pelajar.

Pradotokusumo, Partini Sardjono. (2005). Pengkajian Sastra. Jakarta: PT Gramedia Pustaka Utama 
Titscher, Stefan dkk. (Tanpa tahun). Metode Analisis Teks dan Wacana. Terjemahan oleh Abdul Syukur Gazali, dkk. (Editor: Abdul Syukur Ibrahim). 2009. Surabaya: Pustaka Pelajar.

van Dijk, Teun A. (2004). Ideology and Discourse: A Multidiciplinary Introduction. Barcelona:Universitas Pompeu Fabra,

van Dijk, Teun A. (2004). From Text Grammar To Critical Discourse Analysis A Brief Acadenic Autobiography. Barcelona:Universitas Pompeu Fabra, (Online), (http://www.discoursees.org, diakses 28 Juli 2009).

van Dijk, Teun A. (1998). Ideology: A Multdisciplinary Study. London: Sage Publication.

van Dijk, Teun A. (1997). Sentense Topic and Discourse Topic. (Online), (http://www.discoursees.org, diakses 16 Agustus 2009).

van Dijk, Teun A. (1997). Pragmatic Macro-struktures in Discourse ane Cognition, (Online), (http://www.discoursees.org, diakses 17 Agustus 2009)

van Dijk, Teun A. (1986). Text and Context: Explanation in the Semantics and Pragmatics of Discourse. New York: Longman

van Dijk, Teun A. (1985). Handbook of Discourse Analysis, Vol. 2 Dimnesion of Discourse. New York: Academic Press

van Dijk, Teun A. dan Walter Knitsch. (1983). Strategies of Discourse Comprehension. New York: Academic Press, Inc

Williams, Raymond. (1985). Keywords: A Vocabulary of Culture and Society. Revised edition. New York: Oxford University Press. 